\title{
ANTIPROLIFERATIVE AND APOPTOTIC ACTIVITY OF SULFATED POLYSACCHARIDE ISOLATED FROM HYPNEA VALENTIAE RED SEAWEED IN HUMAN SKIN MALIGNANT MELANOMA CELLS
}

\author{
NEGHA RAJENDRAN, RAMYA RAVICHANDRAN, VEERABHUVANESHWARI VEERICHETTY* \\ Department of Biotechnology, Kumaraguru College of Technology, Coimbatore, Tamil Nadu, India. \\ Email: veerabhuvaneshwari.v.bt@kct.ac.in
}

Received: 15 May 2021, Revised and Accepted: 30 June 2021

\section{ABSTRACT}

Objective: Malignant melanoma is a highly metastatic cutaneous cancer. Deregulated apoptosis has been identified as a major cause of cancer drug resistance. The objective of the study is to evaluate antiproliferative activity of Hypnea Valentiae extract in human skin malignant melanoma (SK-MEL) cells.

Methods: In this study, sulfated polysaccharide fraction was precipitated from aqueous extract obtained from $H$. valentiae. MTT assay was used to determine the cell viability of the crude sulfated polysaccharide against SK-MEL cells and normal L6 cell line (Rat skeletal muscle). Acridine orange (AO) and Ethidium bromide (EB) staining method was applied to study induction of apoptosis in SK-MEL cells.

Results: Dose-dependent reduction in cell viability was observed with an $\mathrm{IC}_{50}$ of $30 \mu \mathrm{g} / \mathrm{ml}$ in SK-MEL cancer cells. The sulfated polysaccharide treated SK-MEL cells followed by AO, EB staining, showed typical early apoptotic, and late apoptotic morphological changes.

Conclusion: The isolated crude sulfated polysaccharide from $H$. valentiae produced potent growth inhibition and induction of apoptosis in SK-MEL cells but caused no cytotoxicity in normal L6 skeletal muscle cells.

Keywords: Anti-proliferative, Cell viability, Cytotoxicity, Human skin malignant melanoma cells, L6 (Rat skeletal muscle cells).

(C) 2021 The Authors. Published by Innovare Academic Sciences Pvt Ltd. This is an open access article under the CC BY license (http://creativecommons.org/ licenses/by/4.0/) DOI: http://dx.doi.org/10.22159/ajpcr.2021v14i8.42048 Journal homepage: https://innovareacademics.in/journals/index.php/ajpcr

\section{INTRODUCTION}

Cancer is one of the leading causes for death throughout the world and the current treatment with chemotherapeutic drugs has a major disadvantage which causes various toxic side effects $[1,7,10]$. Malignant melanoma is aggressive with poor survival rate and is known to have the highest mutational load of all cancers. Several small molecule inhibitors, including vemurafenib and dabrafenib, are successful but long-term treatment has showed that the tumors often become resistant to such inhibitors. Surgery, immunotherapy (a-IFN or interleukin-2) is the limited treatment available for use $[3,6]$. Seaweed, a macroalgae seen in various forms, color and occurs along the coastline line with its biochemical components such as carbohydrates, proteins, vitamins, fat, and minerals $[6,8,9]$. Various bioactive compounds are isolated from seaweeds with antioxidant, antiviral, anti-inflammatory, and anticancer activity $[2,5,25,26]$. Recent studies have shown that they possess health promoting nutrients and phytochemicals that are good in antioxidant activities and cholesterol reducing effects [15]. Furthermore, seaweeds are highly potential in secondary metabolites and sources of dietary fiber that differ chemically and physiochemically, and therefore, they perform different physiological effects on humans $[4,23]$. These metabolites will be useful in the development of new pharmaceutical agents [23]. Thus, the secondary metabolites have potential medicinal applications including antibacterial, antiviral, antitumor, and antifungal activities $[16,26]$. Further the bioactivities of seaweed extracted from red seaweed had opened opportunities in various fields such as pharmaceuticals, cosmeceuticals, nutraceuticals, and functional foods $[12,14,17]$. The present study was performed to examine the effects of sulfated crude polysaccharide on tumor growth inhibition and induction of apoptosis in human skin malignant melanoma cells (SK-MEL), and to determine the cytotoxicity effects in SK-MEL cells in vivo.

\section{METHODS}

Algal collection and sample preparation

The red seaweed (Hypnea valentiae) from Cuddalore coast Tamil Nadu, India. The collected sample was dried for a week until no moisture content was left behind [21,24]. The dried sample was completely homogenized (Fig. 1)

Extraction of polysaccharide from seaweed

Three extracts 10 -g powdered samples were dissolved in $500 \mathrm{ml}$ of distilled water. The boiled extracts of the batches were then cooled down at room temperature and filtered completely (countryman and Whatman filter paper). The $\mathrm{pH}$ of the filtrates was adjusted to 7 to increase the yield of extraction. About $4 \%$ trichloroacetic acid (TCA) was added to the extract and incubated overnight at $4^{\circ} \mathrm{C}$. TCA precipitates the proteins in the extract hence followed by the overnight incubation, the precipitated proteins were removed through centrifugation and the resulting supernatant was collected. To the supernatant of the extract, $1 \%$ calcium chloride was added and incubated overnight at $4^{\circ} \mathrm{C}$. This calcium chloride precipitates the alginic acid present in the extracts and hence they are removed through centrifugation. Followed by this, thrice the volume of absolute ethanol (100\%) was added to the supernatants of the extract and incubated overnight at $4^{\circ} \mathrm{C}$. The precipitated polysaccharides collected through centrifugation. The pellet was completely air dried in the hot air oven [11].

Characterization of seaweed extract by Fourier transform infrared (FTIR) spectroscopy

The nano spray dried seaweed extract was analyzed using Fourier transform infrared spectroscopy (Shimadzu, Japan) with wavelengths in the range of $4000-400 \mathrm{~cm}^{-1}$. The resulting spectra directly correspond to the functional groups present in the structures of given sample [12,13] (Fig .2). 
Cytotoxicity screening by MTT assay

\section{Cell lines and maintenance}

L6 cell line (Rat skeletal muscle) was procured from National Centre for Cell Sciences (NCCS), Pune, India. The cells were cultured in Dulbecco's Modified Eagle's Medium (DMEM-Hi Media), supplemented with 10\% heat inactivated fetal bovine serum (FBS) and $1 \%$ antibiotic cocktail containing Penicillin $(100 \mathrm{U} / \mathrm{ml})$, Streptomycin $(100 \mu \mathrm{g} / \mathrm{ml})$, and Amphotericin B $(2.5 \mu \mathrm{g} / \mathrm{ml})$. The cell containing TC flasks $\left(25 \mathrm{~cm}^{2}\right)$ were incubated at $37^{\circ} \mathrm{C}$ at 5\% CO2 environment with humidity in a cell culture incubator (Galaxy ${ }^{\circledR}$ 170 Eppendorf, Germany). The viability of test sample treated cells was evaluated by direct observation of cells by Inverted phase contrast microscope and further quantified by MTT assay method [27].

\section{SK-MEL Cell lines and maintenance}

SK MEL cell line (Human Skin cancer) was procured from NCCS, Pune, India. The cells were cultured in DMEM-HiMedia, supplemented with $10 \%$ heat inactivated FBS and 1\% antibiotic cocktail containing Penicillin (100 U/ml), Streptomycin $(100 \mu \mathrm{g} / \mathrm{ml})$, and Amphotericin B $(2.5 \mu \mathrm{g} / \mathrm{ml})$. The cells containing TC flasks $\left(25 \mathrm{~cm}^{2}\right)$ were incubated at 370C at 5\% CO2 environment with humidity in a cell culture incubator (Galaxy® 170 Eppendorf, Germany). The viability of test sample treated cells was evaluated by direct observation of cells by Inverted phase contrast microscope. The viability of the treated cells was further quantified by MTT assay method [27].

\section{In vitro MTT cytotoxicity assay}

The monolayer of cells grown in TC flask was exposed to Trypsin/ EDTA solution $(0.025 \%$ trypsin and $0.01 \%$ EDTA in Phosphate

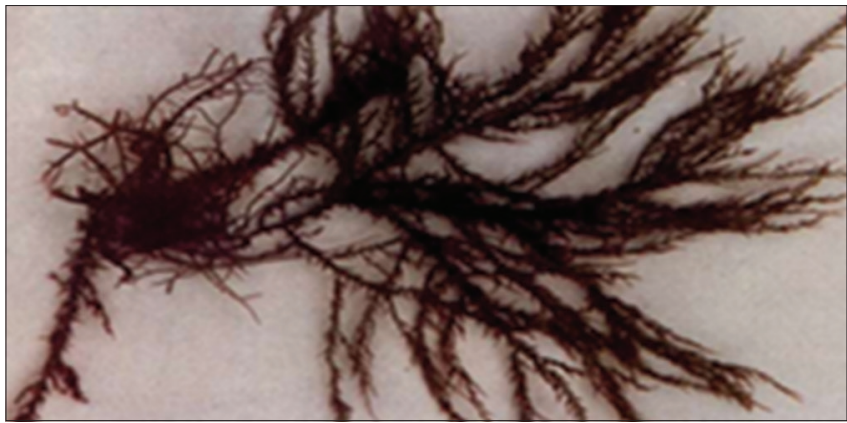

Fig. 1: Hypnea valentiae (Red Seaweed)

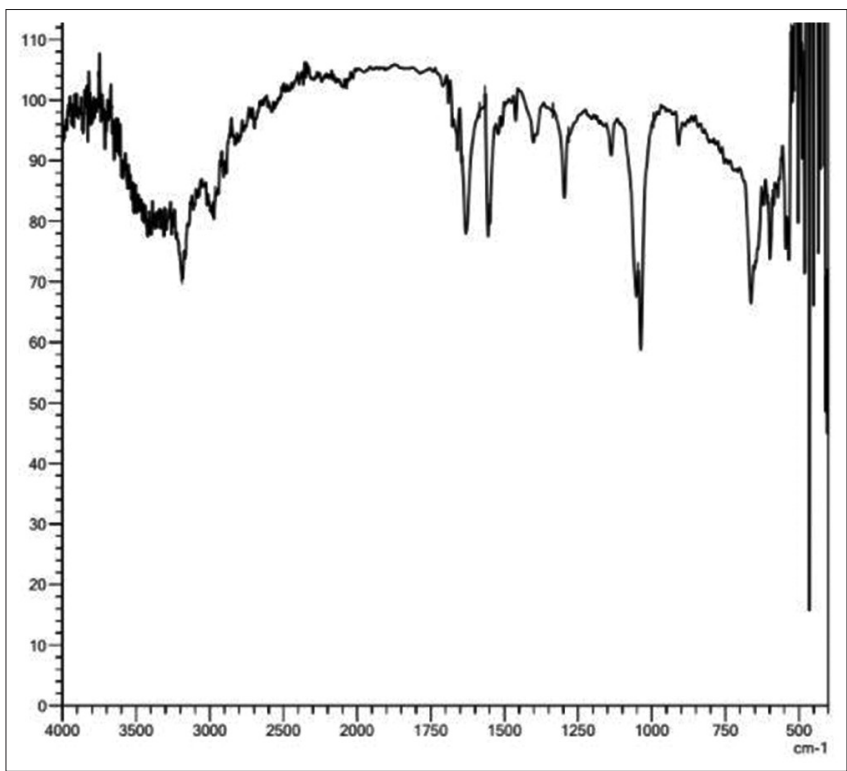

Fig. 2: Characterization of the extract by Fourier transform infrared spectroscopy
Buffered Saline [PBS]). The trypsinized cells were diluted in the cell culture media at a concentration of $5 \times 10^{3}$ cells/well (in $100 \mu \mathrm{l}$ ). The 96 well plates were seeded with cells and incubated for 3-4 days at the cell culture incubator. The test samples were prepared in DMEM media $(100 \mathrm{mg} / \mathrm{ml})$ and filtered using $0.2 \mu \mathrm{m}$ Millipore syringe filters. The samples were further diluted in DMEM media and seeded to the wells containing cultured cells at final concentrations of $6.25 \mu \mathrm{g}, 12.5 \mu \mathrm{g}, 25 \mu \mathrm{g}, 50 \mu \mathrm{g}$, and $100 \mu \mathrm{g}$, respectively. Untreated wells were kept as control. All the experiments were done in triplicate and average values were taken to minimize errors. After treatment with the test samples, the plates were further incubated for $24 \mathrm{~h} \mathrm{[27].}$

\section{Microscopic cytotoxicity observation}

After sample addition, the treated as well as the control wells were observed at regular intervals up to $24 \mathrm{~h}$ in an inverted phase contrast tissue culture microscope (Labomed TCM-400 with MICA PATM HD camera) and the observations were photographed. Any detectable changes in the morphology of the cells, such as rounding, shrinking of cells, granulation, and vacuolation in the cytoplasm were considered as indicators of cytotoxicity $[19,27]$.

Determination of apoptosis by acridine orange (AO) and ethidium bromide (EB) double staining

DNA-binding dyes AO and EB (Sigma, USA) were used for the detection of apoptotic and necrotic cells (Zhang et al, 1998). AO is taken up by both viable and non-viable cells, which emit green fluorescence when they intercalate into double stranded nucleic acid (DNA). EB is taken up only by non-viable cells, which emits red fluorescence by intercalation into DNA. After treatment with different concentrations of the cells were washed by cold PBS and then stained with a mixture of $\mathrm{AO}(100 \mu \mathrm{g} / \mathrm{ml})$ and $\mathrm{EB}(100 \mu \mathrm{g} / \mathrm{ml})$ at room temperature for $10 \mathrm{~min}$. The stained cells were washed twice with $1 \times$ PBS and observed by a fluorescence microscope in a fluorescent microscope (Olympus CKX41 with Optika Pro5 camera) [18]. Thus, the cells were divided into four categories as living cells (normal green nucleus), early apoptotic (bright green nucleus with condensed or fragmented chromatin), late apoptotic (orange-stained nuclei with chromatin condensation or fragmentation), and necrotic cells (uniformly orange stained cell nuclei) [22]

\section{RESULTS AND DISCUSSION}

\section{Extraction of crude sulfated polysaccharide from seaweed}

The seaweed was dried and then powdered and the aqueous extraction and polysaccharide precipitation. The obtained crude extract was spray dried for three batches.

Characterization of crude sulfated polysaccharide by FTIR spectroscopy

The dried sample was analyzed using ATR Fourier transform infrared spectroscopy (Shimadzu, Japan) with wavelengths in the range of 4000$400 \mathrm{~cm}^{-1}$. Similarly, the band at $2974 \mathrm{~cm}^{-1}$ of extract corresponds to the $\mathrm{C}-\mathrm{H}$ stretching. Further, the peak at $1138 \mathrm{~cm}^{-1}$ of extract Corresponds to the C-O-C stretching of glycosidic bonds. The band at $1296 \mathrm{~cm}^{-1}$ of extract corresponds to the $\mathrm{C}-\mathrm{O}$ stretching signifying the presence of aromatic esters. The peak at $906 \mathrm{~cm}^{-1}$ of extract signifies the presence of bending vibration of $\mathrm{C}-\mathrm{O}-\mathrm{S}$ stretching. Hence, from the spectra, it was characterized that the above functional groups are present in the extract.

\begin{tabular}{lll}
\hline $\begin{array}{l}\text { Functional } \\
\text { Group }\end{array}$ & $\begin{array}{l}\text { Peak } \\
\text { Value } \mathbf{~ c m}^{-1}\end{array}$ & Presence/Interpretation \\
\hline CH Stretching & 2974 & CH Stretching of sugars \\
C=O & 1629 & Carboxylic group \\
S=O & 1392,1041 & Sulfate groups connected to sugars \\
C-O-C & 1138 & Stretching of glycosidic bond \\
C-O-S & 906 & Bending vibrations of C-O-S \\
\hline
\end{tabular}




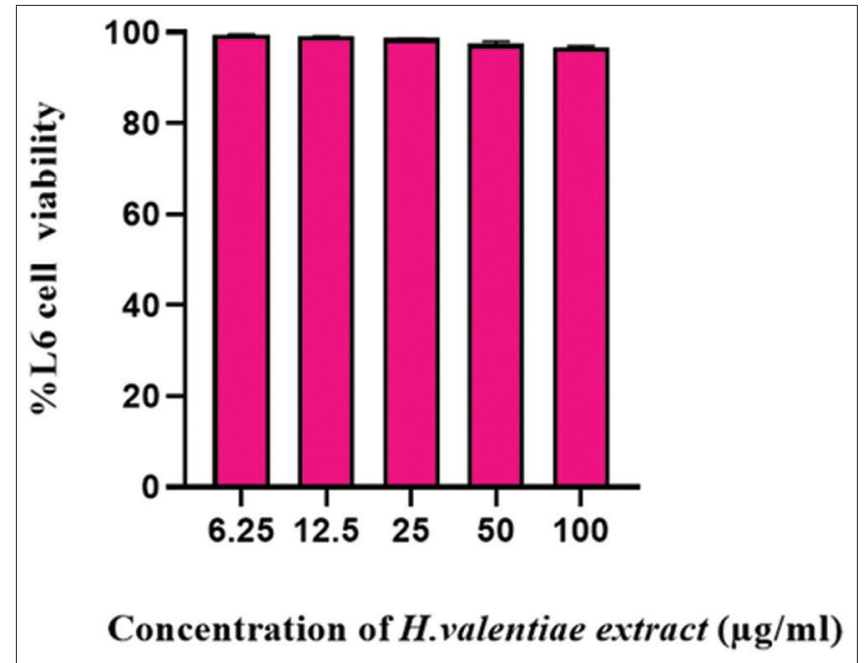

Fig. 3: Effect of sulfated polysaccharide on L6 skeletal muscle cell viability

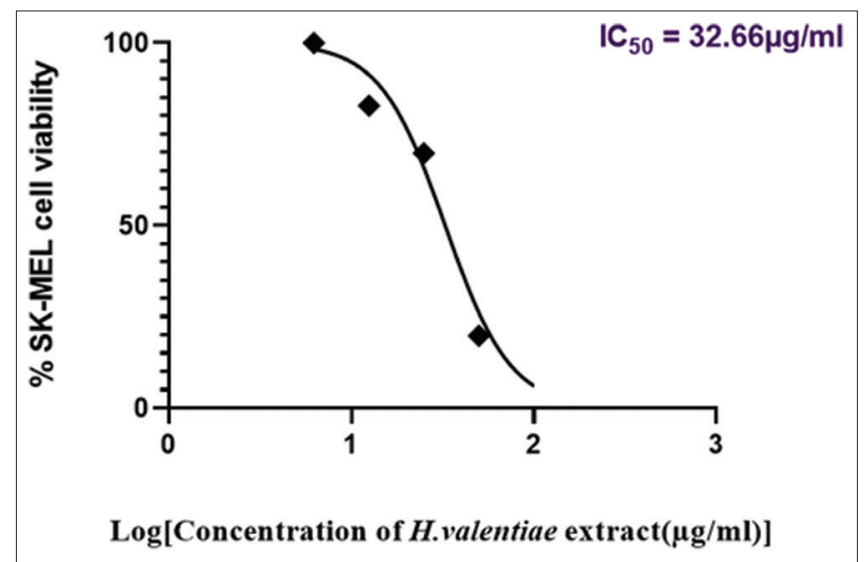

Fig. 4: Effect of sulfated polysaccharide on human skin malignant melanoma 28 cell proliferation

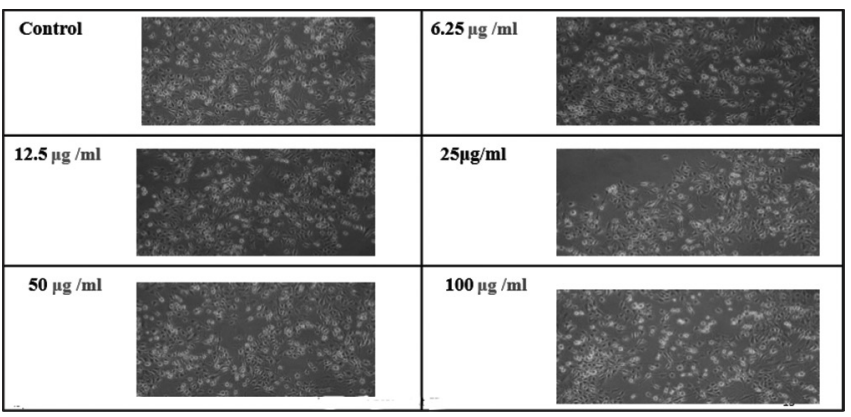

Fig. 5: Cell Viability observation in L6 skeletal cells

Effect of crude sulfated polysaccharide on cell viability Effect of sulfated polysaccharide on L6 skeletal muscle cell viability

The cytotoxicity was absent in L6 rat skeletal muscle cells subjected to the administration of different concentrations of the extract (Fig. 3).

\section{Effect of sulfated polysaccharide on SK-MEL 28 cell viability}

The dose-dependent reduction in cell viability was observed in SK-MEL cancer cells with the administration of different concentrations of the extract with an $\mathrm{IC}_{50}$ of $32.66 \mu \mathrm{g} / \mathrm{ml}$ (Fig. 4).

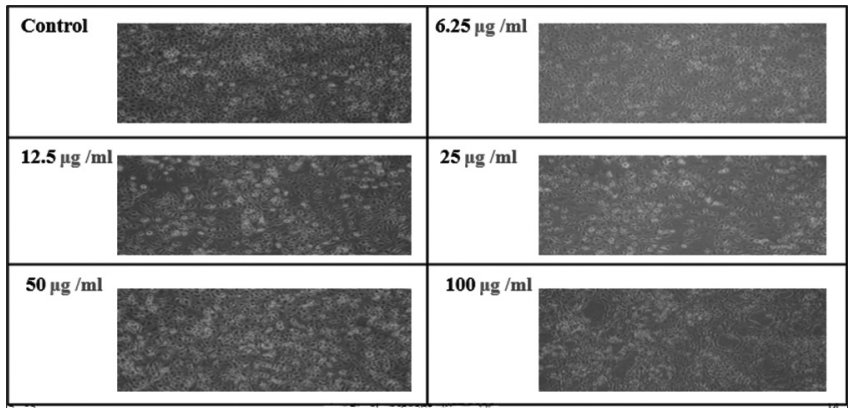

Fig. 6: Cytotoxicity observation in human skin malignant melanoma cells

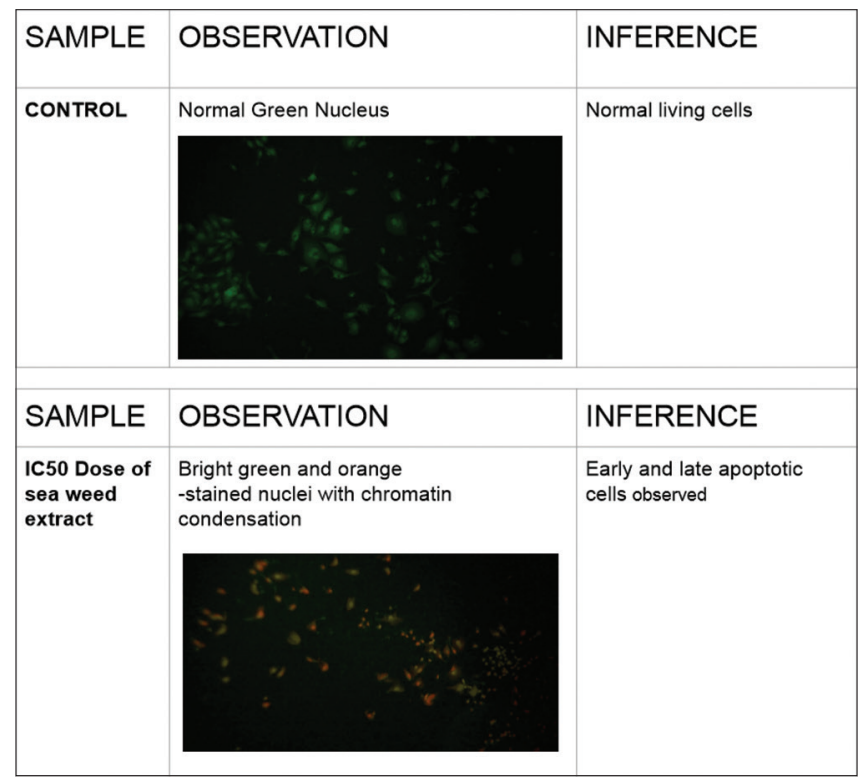

Fig. 7: Induction of apoptosis in SK-MEL28 on treatment with extract

Microscopic cytotoxicity observation

No cytotoxicity was observed in L6 skeletal muscle cells and cells did not show any morphological changes on treatment with crude sulfated polysaccharide (Fig. 5). Cytotoxicity and morphological changes observed in SK-MEL cells on treatment with sulfated polysaccharide on phase contrast microscopic observation (Fig. 6).

Determination of apoptosis by $\mathrm{AO}$ and $\mathrm{EB}$ double staining AO is a vital dye which stains both live and dead cells. EB will stain only the cells that lost membrane integrity, that is, EB will permeate only cells which have lost membrane integrity. Live cells will appear uniformly green. Early apoptotic cells will stain green where the nucleus contains bright green dots because of chromatin condensation and nuclear fragmentation. Late apoptotic cells will also incorporate EB which stains orange but, in contrast to necrotic cells, the late apoptotic cells will show condensed and often fragmented nuclei. Necrotic cells stain orange, but have a nuclear morphology resembling that of viable cells, with no condensed chromatin. The cells were divided into four categories as follows: Living cells (normal green nucleus), early apoptotic (bright green nucleus with condensed or fragmented chromatin), late apoptotic (orange-stained nuclei with chromatin condensation or fragmentation), and necrotic cells (uniformly orange-stained cell nuclei) (Fig. 7). 


\section{CONCLUSION}

The polysaccharide fraction was extracted from H. valentiae. The crude extract was characterized using FTIR. The spectra obtained show the characteristic peaks of sulfated polysaccharide along with additional peaks signifying the presence of other monosaccharides. The antiproliferative activity of extract was identified using MTT cytotoxicity assay in SK-MEL cells. AO and EB staining confirmed apoptosis in SKMEL cells after treatment with extract. From the cytotoxicity assay, it is confirmed that the extract is not cytotoxic and does not affect the cell viability of L6 skeletal muscle cell. AO and EB staining confirmed apoptosis in SK-MEL cells after treatment with extract. The AO/EtBr staining procedure the normal live cells take up the green fluorescence and the IC50 dose shows early and late apoptosis. The crude extract must be purified and characterized to determine the structure of bioactive constituent. Further studies on cell cycle arrest with flow cytometry must be performed. We would like to conclude the crude sulfated polysaccharide from $H$. valentiae shows antiproliferative potential against SK-MEL cells.

\section{AUTHOR CONTRIBUTION}

Negha Rajendran carried out experiment of this research like extraction and FTIR and contributed to manuscript draft preparation and Ramya Ravichandran carried out experiments in L6 and SK-MEL MTT mammalian cell-based assays and Veerabhuvaneshwari Veerichetty participated in Fluorescent $\mathrm{AO}$ and EB ideation and conceptualization, methodology planning, research supervision and data analysis of results and manuscript preparation.

\section{CONFLICTS OF INTEREST}

We declare that we have no known competing financial interests or personal relationships that could have appeared to influence the work reported in this paper.

\section{AUTHOR FUNDING}

No funding received.

\section{REFERENCES}

1. Wróblewska-Łuczka P, Grabarska A, Florek-Łuszczki M, Plewa Z, Łuszczki JJ. Synergy, additivity, and antagonism between cisplatin and selected coumarins in human melanoma cells. Int J Mol Sci 2021;2:537.

2. Bhuyar P, Sundararaju S, Rahim MH, Unpaprom Y, Maniam GP, Govindan N. Antioxidative study of polysaccharides extracted from red (Kappaphycus alvarezii), green (Kappaphycus striatus) and brown (Padina gymnospora) marine macroalgae/seaweed. SN Appl Sci 2021;3:485.

3. Tripathi R, Shalini R, Singh RK. Polyphyletic origin of algae as potential repository of anticancer compounds. In: Evolutionary Diversity as a Source for Anticancer Molecules. Cambridge, Massachusetts: Academic Press; 2021. p. 155-89.

4. González-Ballesteros N, Diego-González L, Lastra-Valdor M, Grimaldi M, Cavazza A, Bigi F, et al. Saccorhizapolyschides are used to synthesize gold and silver nanoparticles with enhanced antiproliferative and immunostimulant activity. Mater Sci Eng C 2021:123:111960.

5. da Silva Barbosa J, Palhares LC, Silva CH, Sabry DA, Chavante SF, Rocha HA. In vitro antitumor potential of sulfated polysaccharides from seaweed Caulerpa cupressoides var. flabellata. Mar Biotechnol 2021;23:77-89.

6. Lomartire S, Cotas J, Pacheco D, Marques JC, Pereira L, Gonçalves AM. Environmental Impact on seaweed phenolic production and activity: An important step for compound exploitation. Mar Drugs 2021;19:245.

7. Moga MA, Dima L, Balan A, Blidaru A, Diminescu OG, Podasca C, et al. Are bioactive molecules from seaweeds a novel and challenging option for the prevention of HPV infection and cervical cancer therapy? A review. Int J Mol Sci 2021;22:629.

8. Ummat V, Sivagnanam SP, Rajauria G, O'Donnell C, Tiwari BK. Advances in pre-treatment techniques and green extraction technologies for bioactives from seaweeds. Trends Food Sci Technol 2021;110:90-106.

9. Cheriyamundath S, Sirisha VL. Marine algal-derived pharmaceuticals: Potential anticancer agents. Encyclopedia Mar Biotechnol 2020;2691-724.

10. Giacone DV, Dartora VF, de Matos JK, Passos JS, Miranda DA, de Oliveira EA, Lopes LB. Effect of nanoemulsion modification with chitosan and sodium alginate on the topical delivery and efficacy of the cytotoxic agent piplartine in 2D and 3D skin cancer models. Int J Biol Macromol 2020;165:1055-65.

11. Kordjazi M, Etemadian Y, Shabanpour B, Pourashouri P. Chemical composition antioxidant and antimicrobial activities of fucoidan extracted from two species of brown seaweeds (Sargassum ilicifolium and S. angustifolium) around Qeshm Island. Iran J Fish Sci 2019;18:

12. Liu Z, Gao T, Yang Y, Meng F, Zhan F, Jiang Q, Sun X. Anti-cancer activity of porphyrin and carrageenan from red seaweeds. Molecules 2019;24:4286.

13. Ghannam A, Murad H, Jazzara M, Odeh A, AllafAW. Isolation, structural characterization, and antiproliferative activity of phycocolloids from the red seaweed Laurencia papillosa on MCF-7 human breast cancer cells. Int J Biol Macromol 2018;108:916-26.

14. Salhi G, Zbakh H, Moussa H, Hassoun M, Bochkov V, Ciudad CJ, et al. Antitumoral and anti-inflammatory activities of the red alga Sphaerococcus coronopifolius. Eur J Integr Med 2018;18:66-74.

15. Sanjeewa KA, Lee JS, Kim WS, Jeon YJ. The potential of brownalgae polysaccharides for the development of anticancer agents: An update on anticancer effects reported for laminaran. Carbohydr Polym 2017;177:451-9.

16. Imbs TI, Ermakova SP, Vishchuk OS, Isakov VV, Zvyagintseva TN. Structural elucidation of polysaccharide fractions from the brown alga Coccophora langsdorfii and in vitro investigation of their anticancer activity. Carbohydr Polym 2016;135:162-8

17. Cunha L, Grenha A. Sulfated seaweed polysaccharides as multifunctional materials in drug delivery applications. Mar Drugs 2016;14:42.

18. Anastyuk SD, Shevchenko NM, Dmitrenko PS, Jazzara MZ, Ghannam A, Soukkarieh C, et al. Anti-proliferative activity of $\lambda$-carrageenan through the induction of apoptosis in human breast cancer cells. Iran J Cancer Prev 2016;9:2012a.

19. Alves C, Pinteus S, Horta A, Pedrosa R. High cytotoxicity and antiproliferative activity of algae extracts on an in vitro model of human hepatocellular carcinoma. Springerplus 2016;5:1-13.

20. Tantirapan P, Suwanwong Y. Anti-proliferative effects of C-phycocyanin on a human leukemic cell line and induction of apoptosis via the PI3K/ AKT pathway. J Chem Pharm Res 2014;6:1295-301.

21. Wijesinghe WA, Jeon YJ. Biological activities and potential industrial applications of fucose rich sulfated polysaccharides isolated from brown seaweeds: A review. Carbohydr Polym 2012;88:13-20.

22. Yeh CC, Tseng CN, Yang JI, Huang HW, Fang Y, Tang JY, et al. Antiproliferation and induction of apoptosis in Ca9-22 oral cancer cells by ethanolic extract of Gracilaria tenuistipitata. Molecules 2012;17:10916-27.

23. Holdt SL, Kraan S. Bioactive compounds in seaweed: Functional food applications and legislation. J Appl Phycol 2011;23:543-97.

24. Athukorala Y, Ahn GN, Jee YH, Kim GY, Kim SH, Ha JH, et al. Antiproliferative activity of sulfated polysaccharide isolated from an enzymatic digest of Ecklonia cava on the U-937 cell line. J Appl Phycol 2009;21:307-14.

25. Yuan YV, Walsh NA. Antioxidant and antiproliferative activities of extracts from a variety of edible seaweeds. Food Chem Toxicol 2006;44:1144-50.

26. Smit AJ. Medicinal and pharmaceutical uses of seaweed natural products: A review. J Appl Phycol 2004;16:245-62.

27. Mosmann T. Rapid colorimetric assay for cellular growth and survival: Application to proliferation and cytotoxicity assays. J Immunol Methods 1983;65:55. 